\title{
Genetically based resistance to the white pine weevil in jack pine and eastern white pine
}

\author{
by Alice Verrez ${ }^{1,2}$, Dan Quiring ${ }^{1,3}$, Thibaut Leinekugel Le Cocq ${ }^{1,2}$, Greg Adams ${ }^{4}$, Yill Sung Park ${ }^{1,5}$
}

\begin{abstract}
White pine weevil (Pissodes strobi Peck) damage was evaluated in one white pine (Pinus strobus L.) and four jack pine (Pinus banksiana Lamb) half-sib family test sites to determine the role of tree genotype in resistance to the weevil. Halfsib family explained a significant proportion of the variation in weevil attack at all sites. Estimates of family (0.16-0.54) and individual (0.09-0.24) heritabilities of jack pine resistance to white pine weevil were moderate. Estimates of family $(0.37)$ and individual $(0.22)$ heritability of resistance of white pine to the weevil were also moderate when the percentage of test trees damaged by the weevil was relatively low, but were insignificant four years later when more than three-quarters of trees were damaged. Significant positive correlations between mean tree height and mean incidence of trees damaged by the weevil were observed for four of seven site-years but relationships were weak, suggesting that any cost, with respect to height growth, to breeding weevil resistant trees may be small.
\end{abstract}

Key words: Pinus, Pissodes strobi, trade-offs, tree improvement, tree resistance, white pine weevil.

\section{RÉSUMÉ}

Les dommages du charançon du pin blanc (Pissodes strobi Peck) ont été évalués dans un site de test de familles de descendance uniparentale de pin blanc (Pinus strobus L.) et dans quatre sites contenant des familles de descendance uniparentale de pin gris (Pinus banksiana Lamb), afin de déterminer le rôle du génotype de larbre dans sa résistance au charançon. La famille a expliqué une proportion significative de la variation dans les attaques du charançon à tous les sites. Les estimations des héritabilités familiales (0.16-0.54) et individuelle (0.09-0.24) de la résistance du pin gris aux attaques du charançon du pin blanc étaient modérées. Les estimations des héritabilités familiale $(0.37)$ et individuelle $(0.22)$ de la résistance du pin blanc au charançon étaient également modérées lorsque le pourcentage d’arbres endommagés par le charançon était relativement bas, mais devenaient non significatives quatre ans plus tard, lorsque plus des trois-quarts des arbres étaient endommagés. Des corrélations positives significatives entre la hauteur moyenne des arbres et la moyenne de lincidence des arbres endommagés par le charançon ont été observées pour quatre des sept sites-années, mais les relations étaient faibles, ce qui suggère que tout coût de la reproduction d’arbres résistants au charançon, par rapport à la croissance en hauteur, pourrait être moindre.

Mots clés : Pinus, Pissodes strobi, compromise, amélioration des arbres, résistance des arbres, charançon du pin blanc

\section{Introduction}

The white pine weevil, Pissodes strobi (Peck), hereafter referred to as WPW, is one of the most important native insect pests affecting economic value of pine (Pinus spp.) and spruce (Picea spp.) regeneration in Canada (Belyea and Sullivan 1956, Alfaro 1989, Alfaro et al. 1996a). By destroying tree leaders, it causes stem deformities and growth losses, which reduce the commercial value of lumber (Brace 1971, Alfaro 1982, Major et al. 2009).

WPW has one generation per year and overwinters in the adult stage. Adults usually emerge in April and fly towards leaders to feed and to mate (Alfaro 1994). Eggs are laid in feeding punctures or in holes specially bored for that purpose, over a period of about a month. Young larvae feed on the cambium of one- and two-year-old stems. By midsummer, each larva bores a deeper chamber in the stem and pupates.
Adults emerge in August and September and after some feeding, seek hibernating sites, most often in the ground beneath the affected tree. Some adults live for up to four years (McMullen and Condrashoff 1973). Weevil attack may destroy up to three years of height growth, as the destruction of the previous year's stem will kill the current year's growth as well (Cozens 1983).

Approximately 20 tree species have been listed as hosts for WPW (MacAloney 1943, Anderson and Fisher 1956) but their susceptibility varies geographically. In eastern North America, eastern white pine (Pinus strobus L.) and jack pine (P. banksiana Lamb) are the most frequently attacked native species, and WPW damage on Norway spruce Picea abies (L.) Karst., an exotic used in plantations, is often as high as that on white pine (MacAloney 1930, 1943; Belyea and Sullivan 1956; Constable et al. 1992; Archambault et al. 1993; Hamel et al

\footnotetext{
${ }^{1}$ Population Ecology Group, Faculty of Forestry and Environmental Management, University of New Brunswick, Fredericton, New Brunswick E3B 6C2

${ }^{2}$ Institut National Agronomique de Paris-Grignon (INA P-G), 16, rue Claude Bernard - 75231 Paris Cedex 05, France

${ }^{3}$ Author to whom correspondence should be sent. E-mail: quiring@unb.ca

${ }^{4}$ J.D. Irving Ltd. Sussex Tree Nursery, 181 Aiton Road, Sussex, New Brunswick E4G 2V5

${ }^{5}$ Canadian Forest Service-Atlantic Forestry Centre, P.O. Box 4000, Fredericton, New Brunswick E3B 5P7
} 
1994; Paradis 1995). Quality defects resulting from weevil damage are particularly important in white pine as premium wood value is obtained for finishing lumber where appearance, including size and distribution of knots, and amount of clear wood is of critical importance. In contrast, Sitka spruce, $P$. sitchensis (Bong.) Carrière, white spruce, P. glauca (Moench) Voss, and interior spruce, a hybrid of white and Engelmann ( $P$. engelmannii Parry) spruce, are the only conifers that have been reported to receive economically serious levels of damage in western North America (Kiss and Yanchuk 1991, Humble et al. 1994, Kiss et al. 1994).

A genetic basis to resistance to WPW has been previously reported for white (Alfaro et al. 1996b), Sitka (Alfaro et al. 2007) and interior (e.g., Kiss and Yanchuk 1991) spruces, as well as for jack pine (de Groot and Schnekenburger 1999), suggesting that tree breeding for resistance is a useful tactic to reduce damage by WPW. Estimates of family and individual heritability of WPW resistance were only reported for interior spruce (Kiss and Yanchuk 1991), which were relatively high ( 0.7 and 0.4 , respectively) indicating that selection of resistant trees would be useful.

Allocation of tree resources to defence against insects could reduce the amount of resources available for growth, maintenance or reproduction (Stearns 1976). Thus, selecting for resistance can have a cost. Although Loehle (1987) reported an inverse relationship between growth rates and tree defence in a comparison among North American conifers, King et al. (1997) reported that the fastest-growing interior spruce trees were also the most resistant to WPW.

The objectives of this study were to determine: (i) the level of genetic variation in jack pine and eastern white pine resistance to WPW, including heritability of variation in damage to WPW; and (ii) to determine if there is a relationship between resistance to weevil attack and tree height.

\section{Materials and Methods Jack pine}

One site from each of four half-sib family tests was evaluated in this study. The four tests are described below.

Athol (Nova Scotia) - Established in 1992 by J.D. Irving Limited. This site contained 45 families, randomly planted in each of 10 blocks (i.e., 450 plots of four trees each $=1800$ trees). Data on WPW damage were collected in 1999 by J.D. Irving personnel and in 2003 by the authors. Tree heights were also measured in 1999.

Donegal (New Brunswick [N.B.]) - Established in 1982 by J.D. Irving Limited. This site contained 84 families randomly planted in each of six blocks (i.e., 504 plots of four trees each $=2016$ trees). White pine weevil damage and tree heights were measured in 1999 by company personnel.

Old Ridge Tree Nursery (N.B.) - Established in 1982 by Georgia-Pacific Corp. This site contained 82 families randomly planted in each of nine blocks (i.e., 738 plots of four trees each $=2952$ trees). White pine weevil damage and tree heights were measured in 1993 by company personnel.

Six Mile Brook (N.B.) - Established in 1982 by Acadia Forest Products. This site contained 68 families randomly planted in each of 10 blocks (i.e., 680 plots of four trees each $=2720$ trees). White pine weevil damage and tree heights were measured in 1993 by company personnel.
In the Athol test in 1999 and in the three other tests, assessment of WPW damage (i.e., dead leader) was done regardless of the year of attack. The data were binary ( 0 for no attack, 1 for presence of attack on the tree). In the Athol test in 2003, data were collected in a different way as damage was recorded for the current and three previous years. The data were binary ( 1 for dead leader, 0 for a live leader) for each of the four years of growth and were summated to produce a score from 0 to $4(0=$ no damage in the last four years, $4=$ damage every year).

In the Athol test in 1999 and in the three other tests, means of damage were calculated for each plot based on the number of live trees. We used individual tree damage ratings for the analysis of data from Athol in 2003, as we had a gradation of values. The influence of tree genotype on resistance to WPW was evaluated using analyses of variance, with family and block as the main factors (PROC VARCOMP; SAS Institute 1982). The following models were used: (1) Damage = Family + Block + Error for the Athol test in 1999 and the three other tests; and (2) Damage $=$ Family + Block + Family $\times$ Block + Error for the Athol test in 2003. Individual heritability estimates were calculated using the equation (Wright 1976):

$$
\text { [1] } \mathrm{h}_{\text {ind }}^{2}=4 \sigma_{\mathrm{F}}^{2} /\left(\sigma_{\mathrm{F}}^{2}+\sigma_{\mathrm{FB}}^{2}+\sigma_{\mathrm{E}}^{2}\right)
$$

where $\sigma^{2}{ }_{F}$ is family variance; $\sigma^{2}{ }_{F B}$ is family $\times$ block variance; and $\sigma_{\mathrm{E}}^{2}$ is within-plot variance.

Estimates of family heritability were calculated using the equation

$$
\text { [2] } \mathrm{h}_{\mathrm{fam}}^{2}=\sigma_{\mathrm{F}}^{2} /\left(\sigma_{\mathrm{F}}^{2}+\sigma_{\mathrm{FB}}^{2} / \mathrm{b}+\sigma_{\mathrm{E}}^{2} / \mathrm{nb}\right)
$$

where $\mathrm{n}$ is the number of trees per plot $(\mathrm{n}=1$ when mean values were used); and $b$ is the number of blocks per site.

The association between family height means and incidence of damage was examined for all sites using correlations between mean damage per plot and mean family height per plot (PROC CORR; SAS Institute 1982). For the Athol test in 2003, mean family heights at age 8 were used as we did not have individual height measurements for the current year. For all the other tests (including the Athol test in 1999), we used tree height data collected the same year as weevil damage data.

\section{White pine}

Data were collected in 1999 and in 2003 in a white pine halfsib family test site planted in 1992 at Athol by J.D. Irving Limited. This site contained 39 families randomly planted in each of 10 blocks (i.e., 390 plots of four trees each $=1560$ trees).

White pine weevil damage was recorded in 1999 by J.D. Irving personnel using a score of 1 or 0 , regardless of the year of attack ( 0 for no attack, 1 for presence of attack on the tree). In 2003, we collected data for the current and three previous years $(0=$ no damage in the last four years, $4=$ damage every year). Tree heights were also measured by J.D. Irving personnel in 1999.

Statistical analyses were conducted in the same way as for jack pine tests. In the analyses of variance, we used mean 
Table 1. Variance component estimates for the effect of half-sib family and block on damage by white pine weevil in four New Brunswick jack pine tests measured during various years from 1994 to 2003 . Estimates of family and individual heritabilities of jack pine resistance to white pine weevil based on damage by white pine weevil is also shown, as is the percentage of trees attacked by the weevil.

\begin{tabular}{lccccc}
\hline & $\begin{array}{c}\text { Old Ridge } \\
\mathbf{1 9 9 4}\end{array}$ & $\begin{array}{c}\text { Athol } \\
\mathbf{1 9 9 9}\end{array}$ & $\begin{array}{c}\text { Six Mile Brook } \\
\mathbf{1 9 9 4}\end{array}$ & $\begin{array}{c}\text { Donegal } \\
\mathbf{2 0 0 0}\end{array}$ & $\begin{array}{c}\text { Athol } \\
\mathbf{2 0 0 3}\end{array}$ \\
\hline$\sigma_{\text {Family }}^{2}$ & $0.00014(2.1 \%)$ & $0.00082(6.1 \%)$ & $0.00038(2.7 \%)$ & $0.00426(5.4 \%)$ & $0.00245(3.2 \%)$ \\
$\sigma_{\text {Block }}^{2}$ & $0.00006(1 \%)$ & $0.00008(0.6 \%)$ & $0.00087(6.4 \%)$ & $0.00742(9.5 \%)$ & $0.00047(0.6 \%)$ \\
$\sigma_{\text {Family x Block }}^{2}$ & - & - & - & - & $0.00275(3.6 \%)$ \\
$\sigma_{\text {Error }}^{2}$ & $0.00656(96.9 \%)$ & $0.01256(93.3 \%)$ & $0.01248(90.9 \%)$ & $0.06656(85.1 \%)$ & $0.07085(92.6 \%)$ \\
$\%$ damage & 2.3 & 5.61 & 6.72 & 38.29 & 7.61 \\
$\mathrm{H}^{2}$ fam & 0.16 & 0.39 & 0.23 & 0.28 & 0.54 \\
$\mathrm{H}^{2}$ ind & 0.09 & 0.24 & 0.28 & 0.24 & 0.13 \\
\hline
\end{tabular}

damage and model (1) for the 1999 data and individual tree damage and model (2) for 2003 data. The association between family height means and incidence of damage was examined using correlations between mean family height at age 8 years per plot and mean damage per plot in 1999 and 2003.

\section{Results and Discussion}

There was a large variation among half-sib families in the percentage of trees attacked by WPW for both jack pine $(2.30 \%-38.29 \%)$ and white pine (15\% and $72.44 \%)$ tests. Variability among half-sib families accounted for a significant proportion of the variation in weevil attack at all sites except in the Athol white pine site in 2003 (Tables 1 and 2). Block variance was higher than family variance in two jack pine tests (Six Mile Brook 1994 and Donegal 2000, Table 1) and in the Athol white pine test (Table 2). This indicates that weevils were aggregated in one area of the site. He and Alfaro (1997) reported that a population of WPW had an aggregated distribution during the early (but not later) stages of colonization of a white spruce stand. In the present study there was no significant difference in damage among half-sib families at Athol in 2003, when the mean percentage of white pine trees damaged by WPW was very high (72.44\%). This suggests that the weevil attacked more resistant trees when the majority of susceptible trees had already been previously attacked.

This is the first time that heritability estimates for the resistance of a pine species to the WPW (Tables 1 and 2) have been reported. The estimates of family and individual heritabilities based on damage were moderate but lower than those reported by Kiss and Yanchuk (1991) for interior spruce in British Columbia, which were 0.7 and 0.4 , respectively. Heritablilities reported in this study were based on natural attack by white pine weevil and block effects were significant. Future investigations could include artificial challenging by introducing weevils into sites, rather than relying solely on natural distribution. This method has been used to obtain better estimates of spruce resistance to WPW in western Canada (Alfaro et al. 2007).

It is important for forest managers to know whether resistance to weevil attack and growth rates of pines are inversely correlated, as reported for spruce in British Columbia (Kiss
Table 2. Variance component estimates for the effect of halfsib family and block on damage by white pine weevil in a white pine test at Athol, New Brunswick. Estimates of family and individual heritabilities of white pine resistance to white pine weevil based on damage by white pine weevil is also shown, as is the percentage of trees attacked by the weevil.

\begin{tabular}{lcc}
\hline Year of measurement & $\mathbf{1 9 9 9}$ & $\mathbf{2 0 0 3}$ \\
\hline$\sigma^{2}$ Family & $0.00179(5.7 \%)$ & $0.00000(0 \%)$ \\
$\sigma^{2}$ Block & $0.01483(29.5 \%)$ & $0.01879(3.1 \%)$ \\
$\sigma^{2}$ Family $\times$ Block & - & $0.03723(6.1 \%)$ \\
$\mathrm{s}^{2}$ Error & $0.03063(64.8 \%)$ & $0.55248(90.8 \%)$ \\
$\%$ Damage & 15 & 72.44 \\
$\mathrm{H}^{2}$ fam & 0.37 & 0.0 \\
$\mathrm{H}^{2}$ ind & 0.22 & 0.0 \\
\hline
\end{tabular}

and Yanchuk 1991, King et al. 1997) because information is important for directing selections in seed orchards and breeding program development (King et al. 1997). We found positive but weak correlations between mean 8-year family height and mean damage in 1999 for the Athol jack pine test and in 1999 and 2003 for the Athol white pine test as well as between mean family height and mean damage in 2000 for the Donegal test (Table 3). As some height measurements were taken after some of the weevil damage occurred, it is probable that our analysis slightly under-estimates the strength of this relationship.

The positive correlations between mean family height and mean damage suggest that faster-growing families of jack pine and white pine could be more attacked. Thus, selection for increased resistance of jack pine and white pine to weevil may have a cost with respect to height growth. However, significant positive correlations were found for four of seven site-years only and relationships were weak, suggesting that any cost may be small. It is important to note that, in the case of white pine, shelterwood harvesting is often prescribed for 
Table 3. Pearson correlations between mean proportion of trees damaged by white pine weevil per plot and mean family height per plot at four jack pine and two white pine tests in New Brunswick that were measured during various years between 1994 and 2003.

\begin{tabular}{lccc}
\hline & $\begin{array}{c}\text { Test site } \\
\text { and year of } \\
\text { measurement }\end{array}$ & $\mathbf{r}$ & $\mathbf{P}$ \\
\hline Jack pine & Old Ridge 1994 & -0.02 & $>0.05$ \\
Jack pine & Athol 1999 & 0.06 & $>0.05$ \\
Jack pine & Six Mile Brook 1994 & 0.06 & $>0.05$ \\
Jack pine & Donegal 2000 & 0.33 & $<0.0001$ \\
Jack pine & Athol 2003 & 0.11 & $<0.05$ \\
White pine & Athol 1999 & 0.22 & $<0.0001$ \\
White pine & Athol 2003 & 0.19 & $<0.05$ \\
\hline
\end{tabular}

providing shade to regenerating white pine in order to reduce weevil damage. This practice reduces light available to the white pine understory which has a cost in growth rate as well as reducing weevil attack (Major et al. 2009).

In contrast to our results, a negative genetic correlation between intensity of white pine weevil damage and tree height has been reported in spruce populations in British Columbia (King et al. 1997). Genetically based resistance of spruces to WPW has been attributed to high resin canal density (Alfaro et al. 1996b, Boucher et al. 2001a), induction of traumatic resin canals after wounding (Alfaro 1995, Tomlin et al. 1998), chemicals that adversely affect weevil reproduction (Sahota et al. 1994), budburst phenology (Hulme 1995, Alfaro et al. 2000) and other mechanisms (e.g., Nicole et al. 2006, Lippert et al. 2007). Although the mechanisms responsible for resistance of pine trees to WPW remains to be determined, it is probably also related to characteristics of leaders. In a comparative study of the performance of WPW on leaders collected from five eastern Canadian conifers, Boucher et al. (2001a, b) showed that WPW performance varied as a function of tree leader characteristics, including the size and density of resin canals. Future research is needed to determine whether similar or different mechanisms are responsible for resistance of jack and white pine to WPW and whether selection for these traits is compatible with other commercially important criteria used in tree breeding programs.

\section{Conclusions}

This study provides encouraging evidence that there is genetic variation in jack pine and white pine resistance to white pine weevil attack as has been documented in spruce species. These results are especially important with respect to white pine regeneration. White pine weevil damage, as well as serious impacts of white pine blister rust (Cronartium ribicola J.C. Fischer) has limited the use of this valuable species in reforestation programs. While shelterwood systems will remain an important white pine management strategy, availability of white pine weevil-resistant stock through traditional tree improvement methods would encourage planting of the species and could help restore the species abundance in the forests of Eastern Canada.

\section{Acknowledgments}

We thank members of the New Brunswick Tree Improvement Council for data collection, Bryce McKinnis for access to data, Kathy Tosh for valuable discussion, and two anonymous reviewers for comments on an earlier version of this manuscript. Funding was provided by a NSERC Discovery grant.

\section{References}

Alfaro, R.I. 1982. Fifty-year-old Sitka spruce plantations with a history of intense weevil attack. J. Entomol. Soc. B.C. 79: 62-65.

Alfaro, R.I. 1989. Stem defects in Sitka spruce induced by Sitka spruce weevil, Pissodes strobi (Peck). In R.I. Alfaro and S.G. Glover (eds.). Insects affecting reforestation: biology and damage. pp. 177-185. Supply and Services Canada.

Alfaro, R.I. 1994. The white pine weevil in British Columbia: biology and damage. In R.I. Alfaro, G. Kiss, and R.G. Fraser (eds.). The White Pine Weevil: Biology, Damage and Management, Proceedings of a Meeting, 19-21, January 1994, Richmond, BC. pp. 7-22. Canadian Forest Service, Pacific Forestry Centre, Victoria, BC. FRDA Report No. 226.

Alfaro, R.I. 1995. An induced defense reaction in white spruce to attack by white pine weevil. Can. J. For. Res. 25: 1725-1730.

Alfaro, R.I., F. He, G. Kiss, J. King and A. Yanchuk. 1996a. Resistance of white spruce to white pine weevil: development of a resistance index. For. Ecol. Manag. 82: 51-62.

Alfaro, R.I., F. He, E. Tomlin, and G.K. Kiss. 1996b. Resistance of white spruce to white pine weevil related to resin canal density Can . J. Bot. 75: 568-573.

Alfaro, R.I., K.G. Lewis, J.N. King, Y.A. El-Kassaby, G. Brown and L.D. Smith. 2000. Budburst phenology of Sitka spruce and its relationship to white pine weevil attack. For. Ecol. Manag. 127: 19-29.

Alfaro, R.I., J.N. King, R.G. Brown, and S.M. Buddingh. 2007. Screening of Sitka spruce genotypes for resistance to the white pine weevil using artificial infestations. For. Ecol. Manag. 255: 1749-1758. Anderson, J.M. and K.C. Fisher. 1956. Repellency and host specificity in the white pine weevil. Physiol. Zool. 29: 314-324.

Archambault, L., J. Morissette and R. Lavallée. 1993. Susceptibility of Norway spruce plantation to white weevil attacks in southern Quebec. Can. J. For. Res. 23: 2362-2369.

Belyea, R.M. and C.R. Sullivan. 1956. The white pine weevil: a review of current knowledge. For. Chron. 32: 58-67.

Boucher, D., R. Lavallée and Y. Maufette. 2001a. Biological performance of the white pine weevil in relation to the anatomy of the resin canal system of four different host species. Can. J. For. Res. 31: 2035-2041.

Boucher, D., Y. Maufette and R. Lavallée. 2001b. Biological performance of the white pine weevil in different host species and in two ecological regions of southern Quebec. Can. J. For. Res. 31: 2026-2034.

Brace, L.G. 1971. Effects of white pine weevil damage on tree height, volume, lumber recovery and lumber value in eastern white pine. Can. For. Serv. Publ. 1303.

Constable, D.C., T. Bouwmeester, W.A. Ingram and S. Melbourne. 1992. Results of forest insect disease surveys in the northeastern region of Ontario. Forestry Canada, Great Lakes Forestry Centre, Sault Ste. Marie, ON. Miscell. Rep. 114.

Cozens, R.D. 1983. The spruce weevil, Pissodes strobi Peck (Coleoptera: Curculionidae). A review of its biology, damage and control techniques with reference to the Prince George Timber Supply Area. B.C. Ministry of Forests, Prince George Forest Region, Prince George, BC. For. Serv. Intern. Rep. PM-PG-3.

de Groot, P. and F. Schnekenburger. 1999. Variation in damage by terminal shoot insects among jack pine families. For. Ecol. Manage. 121: 251-255.

Hamel, M., E. Bauce and R. Lavallée. 1994. Feeding and oviposition interspecific preferences of adult white pine weevil (Coleoptera: Curculionidae) in Quebec. Environ. Entomol. 23: 923-929. 
He, F. and R.I. Alfaro. 1997. White pine weevil (Coleoptera: Curculionidae) attack on white spruce: spatial and temporal patterns. Environ. Entomol. 26: 888-895.

Hulme, M.A. 1995. Resistance by translocated Sitka spruce to damage by Pissodes strobi (Coleoptera:Curculionidae) related to tree phenology. J. Econ. Entomol. 88: 1525-1530.

Humble., M.L., N. Humphreys and G.A. Van Sickle. 1994. Distribution and hosts of the white pine weevil, Pissodes strobi (Peck), in Canada. In R.I. Alfaro, G. Kiss and R.G. Fraser (eds.). The White Pine Weevil: Biology, Damage and Management, Proc. of a Meeting, 19-21 January 1994, Richmond, BC., Canada. pp. 68-75. Can. For. Serv., Pacific Forestry Centre, BC. FRDA Report No. 226.

King, J.N., A.D. Yanchuk, G.K. Kiss and R.I. Alfaro. 1997. Genetic and phenotypic relationships between weevil resistance and height growth in spruce populations of British Columbia. Can. J. For. Res. 27: 732-739.

Kiss, G.K. and A.D. Yanchuk. 1991. Preliminary evaluation of genetic variation of weevil resistance in interior spruce in British Columbia. Can. J. For. Res. 21: 230-234.

Kiss, G.K., A.D. Yanchuk, and R.I. Alfaro. 1994. Recent advances in white pine weevil research in British Columbia. In R.I. Alfaro, G. Kiss, and R.G. Fraser (eds.). The White Pine Weevil: Biology, Damage and Management, Proceedings of a Meeting, 19-21, January 1994, Richmond, BC. pp. 150-157. Canadian Forest Service, Pacific Forestry Centre, Victoria, BC. FRDA Report No. 226.

Lippert, D., S. Chowrira, S.G. Ralph, J. Zhuang, D. Aeschliman, C. Ritland, K. Ritland and J. Bohlmann. 2007. Conifer defense against insects: Proteome analysis of Sitka spruce (Picea sitchensis) bark induced by mechanical wounding or feeding by white pine weevils (Pissodes strobi). Plant Proteomics 7: 248-270.

Loehle, C. 1987. Tree life history strategies: the role of defenses. Can. J. For. Res. 18: 209-222.

MacAloney, H.J. 1930. The white pine weevil (Pissodes strobi Peck) - its biology and control. New York State College of Forestry, Syracuse University, Syracuse, NY. Tech. Publ. 28 p.
MacAloney, H.J. 1943. The white-pine weevil. U.S. Dep. Agric. Circ. 221.

Major, J.E., A. Mosseler, D.C, Barsi, A. Clouthier, and M. Campbell. 2009. Impact of three silvicultural treatments on weevil incidence, growth, phenology, and branch-level dynamics of Pinus strobus from large and small populations. Can. J. For. Res. 39: 12-25. McMullen, L.H. and S.F. Condrashoff. 1973. Notes on dispersal, longevity and over wintering of adult Pissodes strobi (Coleoptera: Curculionidae) on Vancouver island, Canada. J. Entomol. Soc. B.C. 70: 22-26.

Nicole, M.C., R. Lavallée, E. Bauce, M. Charest and A. Séguin. 2006. Stimulating effect of bark polar fraction from the terminal leader of Norway spruce, Picea abies, on white pine weevil, Pissodes strobi, feeding and oviposition. J. of App. Entomol. 130: 284-289.

Paradis, C. 1995. Evaluation des dégâts causes par le charançon du pin blanc. Pissodes strobi (Peck), dans les plantations - relevé de 1993. In R. Lavallée and G. Bonneau (eds.). Compte rendu du Colloque sure le charançon du pin blanc, 27-28 Sept. 1994, Sainte-Foy, QC. pp. 1-10. Ressources naturelles Canada and Ministère des Ressources naturelles du Québec, QC.

Sahota, T.S., J.H. Manville and E. White. 1994. Interaction between Sitka spruce weevil and its Picea sitchensis (Bong) Carr.: A new resistance mechanism. Can. Entomol. 126: 1067-1074.

SAS Institute. 1982. SAS user's guide: Statistics. SAS Institute, Cary, NC.

Stearns, S.C. 1976. Life-history tactics: a review of the ideas. Quart. Rev. Biol. 51: 3-47.

Tomlin, E.S., R.I Alfaro, J.H. Borden and F. He. 1998. Histological response of resistant and susceptible white spruce to simulated white pine weevil damage. Tree Physiol. 18: 21-28.

Wright, J.W. 1976. Introduction to forest genetics. Academic Press Inc., New York. 463 p. 